УДК 619: 616.1/4.591.12.612.23

(C) 2013

Замазій А. А., доктор ветеринарних наук

Полтавська державна аграрна академія

\title{
МОРФОМЕТРИЧНІ ПАРАМЕТРИ РОСТУ І РОЗВИТКУ ПЛОДА КОРІВ ТА АМІНОКИСЛОТНИЙ СКЛАД АМНІОТИЧНОЇ РІДИНИ
}

\section{Рецензент - доктор ветеринарних наук, професор В. О. Свстаф'єва}

\begin{abstract}
Наведено дані стосовно динаміки показників росту й розвитку плода, а також амінокислотного складу амніотичної рідини клінічно здорових новонароджених телят. Встановлено, щзо з кіния першого місяия росту й розвитку ембріона до кіния другого маса його тіла збільшилася в 64,71 разу ( $<<0,001)$. У кінці першого місяия росту й розвитку маса ембріона

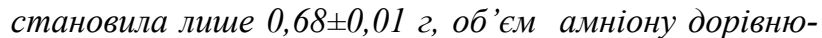

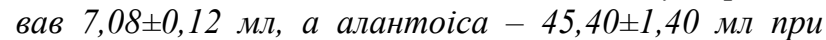

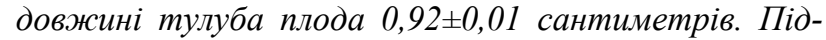
вищення маси тіла плода по місячях росту й розвитку знижується з 64,71 разу в 1,45 разу, а власне маса тіла плода підвищується з $0,68 \pm 0,012$ до 28700,0土5,29 г у порівнянні з попереднім місяцем його росту й розвитку.
\end{abstract}

Ключові слова: плід, ріст, розвиток, амінокислотний склад, амніотична рідина.

Постановка проблеми. Організм вагітних вважають однією з надскладних біологічних систем, що виникла на Землі в процесі еволюції. Підтримання гравідарного гомеостазу в ній забезпечується всіма основними підсистемами: матір'ю, плацентою і плодом. Порушення в одній підсистемі викликає компенсаторні реакції в іншій, що направлені на виконання основної репродуктивної задачі - виношування та народження здорового приплоду. 3 огляду на це, важливого значення набувають питання щодо знань морфометричних показників росту та розвитку плода та склад амніотичної рідини за умов фізіологічного протікання вагітності тварин $[1-3,6]$.

Чимало авторів вказує на те, що тільки 7-15\% новонароджених тварин здатні адаптуватися до умов існування після народження. Решта ж тварин народжується 3 певною мірою внутрішньоутробної недорозвиненості, передусім системи дихання та імунокомпетентних структур і органів [3; 6-10]. Характерною особливістю зниження життєздатності неонатальних продуктивних тварин є їх $100 \%$ захворювання в перші дні життя. Летальні випадки серед телят, поросят, ягнят, курчат, які захворіли, часто досягають $50 \mathrm{i}$ більше процентів. Перехворілі тварини відстають у рості й розвитку і надалі до $35 \%$ не реалі- зують генетичного потенціалу племінних якостей $\mathrm{i}$ продуктивності [4, 5].

Тому для вирішення існуючої проблеми в тваринництві необхідно насамперед на глибоко науковій основі формувати ветеринарну неонатологію, проблеми якої пов'язані 3 вирішенням задач із вирощування здорових високопродуктивних тварин $[1,2,4]$.

Проведені дослідження були складовою частиною тематичного плану «Розробка мультипараметричної системи виробництва молока на основі секретоутворюючої функції молочної залози, пре- та постнатального розвитку тваринного організму і методів їх корекції», № державної реєстрації 0108U010281 (Розділ 2. «Фізіологобіохімічні параметри пре- та постнатального розвитку тварин та їх корекція»).

Аналіз основних досліджень і публікацій, у яких започатковано розв'язання проблеми. Будь-яка система утримання та вирощування телят [6] не може забезпечити отримання здорових тварин із високою продуктивністю, якщо вона не враховує морфофункціональних особливостей росту й розвитку плода та новонароджених тварин $[4,5,14]$. Одним із завдань першочергової важливості в цілях розробки заходів, направлених на підвищення адаптативних здатностей організму, $є$ знання фізіологічних основ росту і розвитку організму у пре- та постнатальні періоди життєдіяльності $[4,5]$. Окремі автори вважають, що критичні періоди життедіяльності організму спостерігаються в основному на ранніх термінах пре- та постнатального росту й розвитку. Нормальний ріст і розвиток плода багато в чому визначається особливостями кровообігу у системі «мати - плацента - плід». Первинний дефект плацентації призводить до порушень серцево-судинної адаптації та перфузії плаценти. Порушення матково-плацентарно-плодової геодинаміки у ранній період вагітності $є$ причиною первинної плацентарної недостатності i, як наслідок, - важких ускладнень вагітності та розвитку гіпоксії плода й новонароджених тварин [710]. За результатами досліджень у системі гомеостазу у корів сухостійного періоду відбува- 


\section{ВЕТЕРИНАРНА МЕДИЦИНА}

ються істотні зміни, які є елементами фізіологічної адаптації, що забезпечує функціонування цілісності гемоциркуляції в організмі самки і плода [11-17].

В зв'язку 3 цим значної уваги необхідно надавати дослідженню фізіологічних основ росту й розвитку плода, складу амніотичної рідини, поскільки знання та аналіз причин, які їх викликають, сприяють розробці способів і прийомів отримання життєздатного приплоду, підвищення відтворної функції корів.

Мета досліджень - дослідити морфометричні параметри росту й розвитку плода та амінокислотний склад амніотичної рідини за умов фізіологічного протікання тільності у корів.

Завдання: дослідити параметри росту й розвитку плода та амінокислотний склад амніотичної рідини за умов протікання фізіологічної тільності корів.

Матеріали та методи досліджень. Лабораторні дослідження проводилися в умовах кафедри патологічної анатомії та патофізіології Полтавської державної аграрної академії, анатомії, нормальної та патологічної фізіології тварин Сумського національного аграрного університету, відділу № 20 Інституту прикладної фізики НАН України (м. Суми).

3 метою дослідження показників росту і розвитку плода в умовах двох м'ясокомбінатів (ТОВ «Ворожба» м’ясокомбінат Білопільського району Сумської області та ПАТ «Конотопм'ясо» (м. Конотоп Сумської області) використовували корів української чорно-рябої та української червоно-рябої порід другої-четвертої лактацій. Інформація щодо осіменіння корів після отелення отримана від власників тварин i спеціалістів господарств.

Після забою корів за наявності плода визначали період його гестації, довжину його тулуба (см), масу тіла (кг), кількість амніотичної та алантоїсної рідин (мл), відбирали проби амніотичної рідини й крові з серця плода або пупкової артерії.

Період гестації плода визначали за його промірами i наявністю шерстяного покрову за В. С. Шипіловим, Г. В. Звєрєвою, І. І. Родіним та В. Я. Нікітіним (1988 р.) і корів відносили до групи тварин у відповідному періоді лактації та росту і розвитку плода.

На амінокислотному аналізаторі Biotronik LC6001 (Німеччина) 3 інтегратором SP-4100 на основі післяколонкової реакції 3 нінгідрином проводили дослідження амінокислотного складу рідин гомеостатичного рівня організації функці- ональноактивних новонароджених телят.

Результати досліджень. Результати проведених нами досліджень свідчать, що динаміка маси тіла плода впродовж періоду його росту та розвитку мала наступну характеристику (табл. 1).

Необхідно відмітити, що з кінця першого місяця росту й розвитку ембріона до кінця другого місяця маса його тіла збільшилася в 64,71 разу $(\mathrm{p}<0,001)$. Маса тіла ембріона становила напри-

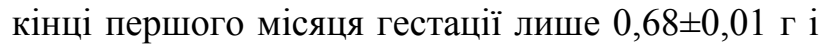
підвищилася до кінця другого місяця до $44,0 \pm 1,16$ г.

Далі, у порівняні з попереднім місяцем гестації, маса тіла плода кількісно збільшується, однак у разовому розрахунку цей показник знижується.

Встановлено, що маса тіла плода в кінці третього місяця росту й розвитку становила 287,0 $\pm 1,57$ г і підвищилась порівнянно $з$ попереднім місяцем гестації лише в 6,50 разу.

Від третього до четвертого місяця гестації маса тіла плода підвищилася до $1628,0 \pm 2,92$ г, що лише в 5,72 разу більше даного показника у попередній місяць. 3 п’ятого місяця гестації плода до кінця дев'ятого маса тіла плода підвищується, відповідно, в 2,70, 1,57, 1,64, 1,75 та 1,48 разу $(\mathrm{p}<0,001)$.

За вищезазначений період у кількісному вимірі маса тіла плода підвищилась 3 1628,0 $\pm 2,92$ г до $28700,0 \pm 5,29$ грамів. Результати досліджень свідчать, що впродовж усього періоду гестації плода об'єм рідини в амніоні та алантоїсі поступово вірогідно підвищується. Довжина тулуба плода за дев'ять місяців гестації збільшується майже в сто

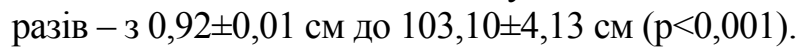

Маса тіла тільних корів також змінювалася впродовж усього періоду тільності. Вона знизилася від третього місяця лактації до четвертого

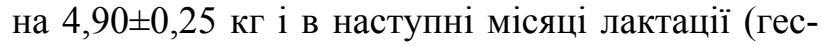
тації плода) збільшилася до 644,8 $\pm 5,42$ кг (у 1,24 paзy, $\mathrm{p}<0,01)$.

Молочна продуктивність корів знижувалася впродовж періоду лактації в 3,40 разу ( $<0,001)$.

Результати наших досліджень свідчать, що загальний вміст амінокислот у навколоплідній рідині клінічно здорових новонароджених телят становив 330,39 7,,52 нмоль/0,1 мл.

Вміст вільних амінокислот (табл. 2) у амніотичній рідині клінічно здорових телят був на рівні 222,97 $\pm 3,82$ нмоль/0,1 мл.

Із них на частку незамінних амінокислот при-

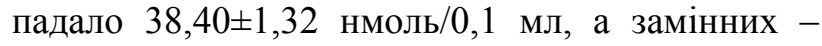
$184,57 \pm 3,44$ нмоль/0,1 мл. 
ВЕТЕРИНАРНА МЕДИЦИНА

\section{1. Маса тіла плода та об’єму навколоплідної рідини, $(M \pm m, n=5)$}

\begin{tabular}{|c|c|c|c|c|c|}
\hline \multirow{2}{*}{$\begin{array}{c}\text { Місяць } \\
\text { гестації } \\
\text { плода }\end{array}$} & \multirow{2}{*}{$\begin{array}{l}\text { Маса тіла } \\
\text { плода, г }\end{array}$} & \multicolumn{2}{|c|}{ Об’єм рідини, мл } & \multirow{2}{*}{$\begin{array}{c}\text { Довжина тулуба } \\
\text { плода, см }\end{array}$} & \multirow{2}{*}{$\begin{array}{c}\text { Підвищення } \\
\text { маси тіла } \\
\text { плода, разу }\end{array}$} \\
\hline & & амніона & алантоїса & & \\
\hline 1 & $0,68 \pm 0,01$ & $7,08 \pm 0,12$ & $45,40 \pm 1,40$ & $0,92 \pm 0,01$ & - \\
\hline 2 & $44,0 \pm 1,16$ & $112,00 \pm 1,52$ & $157,00 \pm 1,92$ & $6,72 \pm 0,51$ & 64,71 \\
\hline 3 & $287,0 \pm 1,57$ & $738,00 \pm 2,63$ & $879,40 \pm 3,93 * * *$ & $14,24 \pm 1,41$ & 6,50 \\
\hline 4 & $1628,0 \pm 2,92$ & $2087,00 \pm 3,92 * * *$ & $1671,00 \pm 3,04$ & $22,80 \pm 2,08 * * *$ & 5,72 \\
\hline 5 & $4401,0 \pm 3,23$ & $3505,00 \pm 3,10$ & $2102,40 \pm 3,70 * *$ & $35,64 \pm 1,49$ & 2,70 \\
\hline 6 & $6901,0 \pm 5,81 * *$ & $3620,67 \pm 4,63 * *$ & $2789,67 \pm 3,76^{* * *}$ & $52,67 \pm 4,29 * *$ & 1,57 \\
\hline 7 & $11300,0 \pm 6,06$ & $5723,00 \pm 54,69$ & $4087,33 \pm 4,67$ & $68,10 \pm 4,53 *$ & 1,64 \\
\hline 8 & $19801,0 \pm 8,09^{* *}$ & $11286,67 \pm 4,63$ & $5644,00 \pm 3,79 * *$ & $81,50 \pm 4,19$ & 1,75 \\
\hline 9 & $28700,0 \pm 5,29$ & $12544,00 \pm 8,08$ & $6980,33 \pm 6,06$ & $103,10 \pm 4,13$ & 1,45 \\
\hline
\end{tabular}

Примітка: * $<<0,05 ; * * \mathrm{p}<0,01 ; * * * \mathrm{p}<0,001$ - порівняно $з$ попереднім місяцем

\section{2. Загальні показники амінокислотного складу навколоплідної рідини новонароджсених клінічно} здорових телят (М \pm m, нмоль/0,1 мл, $n=5)$

\begin{tabular}{|c|c|}
\hline Показник & Клінічно здорові телята \\
\hline Усього & $330,39 \pm 7,52$ \\
\hline Вільні амінокислоти & $222,97 \pm 3,82$ \\
\hline Незамінні амінокислоти & $38,40 \pm 1,32$ \\
\hline Замінні амінокислоти & $184,57 \pm 3,44$ \\
\hline Вміст глюкопластичних амінокислот & $39,32 \pm 0,32$ \\
\hline Вміст ліпопластичних амінокислот & $20,01 \pm 1,24$ \\
\hline
\end{tabular}

Аналіз амінокислотного складу навколоплідної рідини клінічно здорових новонароджених телят (контроль) дав змогу встановити, що у ній значно більшим був вміст компонентів, які беруть участь в орнітиновому циклі.

Основною амінокислотою, що бере участь на початковому етапі даного циклу, є орнітин.

Ïї вміст у амніотичній рідині клінічно здорових новонароджених телят становив $3,43 \pm 0,04$ нмоль $/ 0,1$ мл, а у телят, які народилися у стані гіпоксії, даний показник був у 10,09, 3,30 $(\mathrm{p}<0,001)$ та 1,26 рази меншим $(\mathrm{p}<0,05)$.

Цитруліну у навколоплідній рідині клінічно здорових телят виявлено на рівні $3,91 \pm 0,25$ нмоль/0,1 мл.

У перспективі дослідження 3 даного напряму дадуть можливість встановити фізіологічні параметри росту й розвитку плода, сприяючи розробці способів і прийомів отримання життєздатного приплоду та підвищенню відтворної функції корів.
Висновки: 1. Встановлено, що у порівняні 3 попереднім місяцем гестації маса тіла плода кількісно збільшується, однак у разовому розрахунку цей показник знижується.

2. Доведено, що з кінця першого місяця росту й розвитку ембріона до кінця другого маса його тіла збільшилася найбільш суттєво - в 64,71 разу $(\mathrm{p}<0,001)$.

3. Загальний вміст амінокислот у навколоплідній рідині клінічно здорових новонароджених телят становив 330,39 \pm ,52 нмоль/0,1 мл, вільних амінокислот - 222,97 $\pm 3,82$ нмоль/0,1 мл. Із них на частку незамінних амінокислот припадало $38,40 \pm 1,32$ нмоль $/ 0,1$ мл, а замінних $184,57 \pm 3,44$ нмоль $/ 0,1$ мл.

4. У навколоплідній рідині клінічно здорових новонароджених телят високим виявся вміст компонентів, які беруть участь в орнітиновому циклі.

5. Вміст орнітину в амніотичній рідині клінічно здорових новонароджених телят становив $3,43 \pm 0,04$ нмоль/0,1 мл, а цитруліну $-3,91 \pm 0,25$ нмоль/0,1 мл. 


\section{БІБЛІОГРАФІЯ}

1. Гаврилін П. М. Концепція підвищення життєздатності новонароджених телят / П. М. Гаврилін, Б. В. Криштофорова, Д. М. Масюк [та ін.] // Вісник Дніпропетровського ДАУ. - 2004. - №1. - С. 96-98.

2. Замазій $A$. A. Трансформація депонованої енергії на продукцію у корів і ії вплив на зрілість сурфактантно-альвеолярної системи новонароджених телят / М. Д. Камбур, А. А. Замазій // Вісник Сумського НАУ. - 2006. - № 1-2. C. 61-63.

3. Замазій А. А. Влияние биоэлементов на метаболическую адаптацию новорожденных телят / А. А. Замазій, М. Д. Камбур, В. М. Клемазов // Материалы 10-й Международной научно-произ. конф. «Проблеми сельскохозяйственного производства на современном этапе и пути их решения», Россия, Белгород, 15-19 мая 2006 г. - Т. 2. - С. 121.

4. Замазій A. А. Жирнокислотний склад крові та навколоплідних рідин функціонально активних новонароджених телят / А. А. Замазій // Науковотехнічний бюлетень Інституту біології тварин. Львів, 2008. - Вип. 9, №3. - С. 48-52.

5. Замазій А. А. Лікування гіпоксії новонароджених телят / А. А. Замазій // Науковий вісник Львівського національного університету ветеринарної медицини та біотехнології ім. С. З. Гжицького. - Львів, 2009. - Т. 11, №2 (41). - Ч. 1. C. 76-79.

6. Замазій A. A. Корекція гіпоксії новонароджених телят / А.А. Замазій // Вісник Сумського НАУ. - 2009. - №2 (23) . - C. 29-33.

7. Замазій $A$. А. Секретоутворююча функція молочної залози та життєздатність приплоду у корів / М. Д. Камбур, А. А. Замазій // Монографія. - Суми, 2009. - 172 с.

8. Замазій $A$. А. Амінокислотний склад навколоплідної рідини функціонально активних та гіпоксичних новонароджених телят / А. А. Замазій, М. Д. Камбур // Науковий вісник Львівського національного університету ветеринарної медицини та біотехнології ім. С. 3. Гжицького. -
2010. - Т.12, №2 (44). - Ч. 2. - С. 92-95.

9. Замазій $A$. А. Амінокислотний склад навколоплідної рідини функціональноактивних новонароджених телят / А. А. Замазій, М. Д. Камбур // Вісник Сумського національного аграрного унту. - 2010. - №3 (26). - С. 56-59.

10. Криштофорова Б. В. Біологічні основи ветеринарної неонатології / Б. В. Криштофорова, В. В. Лемещенко, Ж. Г. Стегней. - Сімферополь : Терра Таврика, 2007. - 368 с.

11. Камбур М. Д. Вплив енергетичного забезпечення організму корів на секреторну функцію молочної залози і життєздатність приплоду / М. Д. Камбур, А. А. Замазій // Науково-технічний бюлетень Інституту біології тварин, ДНДКІ ветпрепаратів та кормових добавок. - Львів, 2009. - Вип. 10. - № 1, 2. - С. 45-50.

12. Калиновський Г. М. Морфофункціональне обгрунтування раціональної профілактики акушерської патології у корів: автореф. ... докт. вет. наук: спец. 16.00.07. «Ветеринарне акушерство». - Львів, 1993. - 33 с.

13. Косенко М. В. Азбука ведення тваринництва / М. В. Косенко, О. Г. Малик. // Львів : Добра справа, 2001. - $300 \mathrm{c}$.

14. Криштофорова Б. В. Проблемы ветеринарной неонатологии / Б. В. Криштофорова // Науковий вісник Національного аграрного університету. - 1998. - Вип.11. - С. 115-117.

15. Любеиький В. Й. Біохімічний статус крові корів до і після родів у нормі та при патології / В. Й. Любецький // Вісник аграрної науки. 1997. - №8. - C. 37-41.

16. «Сурфакта ЗКФ» - біостимулятор адаптивних систем новонароджених телят у рібілдингперіоді / А. А. Замазій // Зб. наукових праць ХДВВА. - Вип. 20. - Ч. 2, Т. 2. - С. 279-283.

17. Яблонський В. А. Проблеми відтворення тварин на рубежі XXI століття / В. А. Яблонський // Науковий вісник Національного аграрного університету. - К., 2000. - №22. - С. 16-21. 